\title{
Understanding the Complexities and Resource Sustainability in Afram Plains, Ghana
}

\author{
Mark Appiah \\ University of Eastern Finland, Faculty of Science and Forestry, School of Forest Science \\ PO Box 111, 80101 Joensuu, Finland
}

Tel: 358-132514499Ｅ-mail: mark.appiah@uef.fi

Received: January 15, 2013 Accepted: January 26, 2013

doi:10.5296/emsd.v2i1.3040～URL: http://dx.doi.org/10.5296/emsd.v2i1.3040

\begin{abstract}
The main objective of the study was to determine the key driving forces behind the ever increasing problem of tree species loss and environmental degradations in the Afram plains and propose management action areas for reducing the loss. The study used participatory research method tools to assess farmers' views on their livelihood strategies and the causes of dwindling forest resources in the area. There may be many forces jeopardising forest resources in the study area but charcoal production was reported as the single most important factor driving the loss of tree species in the area. Charcoal burning was becoming increasingly a full time occupation for many young people as their families struggle with poor soil fertility and declining agricultural productivity. There is, therefore, the need to consider financial and technological investment in agricultural diversification to be able to reduce biodiversity loss within the agroecosystems of the area. It will significantly help these forest dependent communities to diversify their economies and soften the impacts of charcoal production and farming activities on the agroecosystem biodiversity. In addition, due to low level capabilities of local people, an effective and efficient implementation of educational programs is needed to enhance their capabilities in managing agroecosystems. Finally, it worth emphasising that efforts to reduce forest tree species loss and environmental degradation will be jeopardised or eventually be unsustainable unless project initiators address cash income and energy needs of local people. Agroforestry systems including plantations development could be part of the solutions to sustainable management of the agroecosystems in the area.
\end{abstract}

Keywords: Agroecosystems, agricultural diversification, biodiversity loss, charcoal production, local opinion 


\section{Introduction}

The dry semi-deciduous (DS) forest zone covers approximately 26\% of the tropical forest in Ghana (Wagner et al., 2008), and constitutes the transition zone between the higher rainfall types and the Guinea savannah. Although the DS forests serve diverse ecological functions and provide numerous environmental and socio-economic benefits to society, particularly the rural people (Appiah, 2001; Appiah et al., 2009; Appiah et al., 2010), their capacity to provide these services and benefits to society on a sustained basis has been continuously threatened by massive forest destruction. This has resulted in significant vegetation changes and environmental degradation (Repetto, 1988; Hawthorne, 1989; IUCN, 2006, FRA, 2010). Anthropogenic activities such as conversion of forest lands to agriculture, illegal logging, and wildfires have been cited as some of the causes of the vegetation changes and biodiversity loss in the region (Appiah, 2001; Appiah et al., 2009; Appiah et al., 2010. These anthropogenic activities have accelerated sharply in the past decade due to the increasing population and changing livelihood trends.

Unfortunately, the ecosystems that are able to sustain the human, especially, local people's livelihood are not limitless, and while vegetation changes to some ecosystems (sensitive ones) may take decades to recover others may not be able to recover at all from severe changes (Appiah, 2013). There is a need, therefore, to manage the forest ecosystems and natural resources in such a way that both human and animal life forms can be supported on in a sustainable way. This is actually the main focus of sustainable development as highlighted by the UN World Commission on Environment and Development and in the Convention on biological diversity document (Brundtland, 1987). But implementing sustainable natural resources management programmes have encountered place-specific cultural barriers that often go unrecognized. While there can be consensus among scholars and development practitioners on the causes of deforestation and environmental degradation (e.g. shifting cultivation, land tenure, illegal logging, annual wildfires, political will and economic interests of individuals and institutions in society(Grainger, 1993; Wagner and Cobbinah, 1993; Hawthorne, 1994; Angelsen, 1995; Geist and Lambin, 2001; Geist and Lambin, 2002; Karousakis, 2006; Appiah, 2011)), successful implementation of sustainable programmes to address these causes has been notoriously complex and increasingly becoming a daunting task.

In Ghana for instance, forest species loss and other ecological problems are far more serious today than ever before despite the government's policy, legislative and institutional reforms and log exports banned since 1995 and chain saw illegal logging prohibition since 1998 (Bamfo, 2005). Similarly, in other regions, an analysis of 194 World Bank projects with the objectives of alleviating poverty and protecting biodiversity revealed that only $16 \%$ made major progress on both objectives and were judged to be sustainable (Tallis et al., 2008). Although some of these conservation and management efforts have resulted in some success stories, just as many strategies have wrought serious failures (Ostrom, 2007). Part of the reasons for the failures is rooted in the fact that basic "conservation and management strategies are designed in academia and then applied too generally, in a 'top-down' and often as an inflexible, regulatory 'blueprint' that foolishly ignores local culture, economics, and 
social behaviour” (Ostrom, 2007). This approach often leads to disagreements between local stakeholders and development practitioners (including government agencies) on what they see as the actual problem or causes of forest biodiversity loss (Appiah, 2001). Top-down approach also has often led to disagreement about the control of the forests and the selection of appropriate forest management strategies (Byron 1997; Appiah, 2001) consequently the various interest groups are left to advance their respective interests. These conflicting perspectives among the key different interest groups in resources management can sometimes bring development actions to a standstill or make them unsustainable (Reid and Schwab, 2006). A more relevant concern for the premise of this study is that project initiators often fail to conduct adequate local assessments on land resources, local knowledge, local institutions, and capabilities. These kinds of assessments are basically required by any resource manager before introducing management plans (Miller, 1997, Byron, 1997). For failing to do these assessments, the consequence is a mismatch of priorities between local stakeholders and development practitioners (Appiah, 2001) and the application of one-size-fits-all solution to issues of forest loss and degradation.

However, from all these failures, some lessons have been learnt and a new phase of problem solving is taking hold where researchers and development practitioners are moving from generalization to dealing with the issues of sustainability in contextual manner (FAO/ITTO/INAB, 2003, FAO, 2003). But, moving towards this direction requires the understanding of the complexities of how local strategies and cultures interact with nature and its resources. Studies are needed to reveal local thoughts on resources sustainability and the practices that are highly meaningful to local communities, but remain invisible to outsiders. This information can help to determine the key localized factors influencing natural resource management or environmental degradation and consequently help to be able to formulate and introduce more sustainable development concepts or projects (Appiah et al., 2009). In this paper, the key driving forces behind land use changes in the Afram plain were assessed and management action areas proposed to shape the development of the ecosystems in the area. In particular, this study is to provide insight into the thought of the local people as to how the changes in the agroecosystems occurred.

\section{Literature Review}

\subsection{The Concept of Sustainable Development}

The concept of sustainable development was introduced as early as 1972 at the United Nations Conference on the Human Environment in Stockholm, Sweden (Palanivel, 1999) and later the concept was fully defined in 1987 in the Brundtland Report (named after the Norwegian Prime Minister who chaired the U.N. Commission authoring the report), as development that meets the "needs of the present without compromising the ability of future generations to meet their own needs" (Brundtland, 1987; Palanivel, 1999). Furthermore, at the "Earth Summit" meeting organised by the United Nations in Rio De Janeiro in 1992, ways for achieving sustainable development were agreed upon in "Agenda 21", which recognised the integration of environment and development concerns and suggested that greater attention paid to both aspects would lead to the fulfilment of people's basic needs, 
improvement of the living standards for all, and enhancement in the protection and management of ecosystems. Obviously, there is no single definition for the term 'sustainable development, however, according to the World Commission on Environment and Development, these definitions represent two key concepts: "the concept of 'needs', in particular the essential needs of the world's poor, to which overriding priority should be given"; and the idea of limitations imposed by the state of technology and social organization on the environment's ability to meet present and future needs (Brundtland, 1987; World Commission on Environment and Development, 1992). This assertion suggests that conservation and development projects should be able to achieve ecological, economic and social progress along with other project primary goals. Under the framework for sustainable development, equity is an economic objective that needs to be achieved. Social objectives to be achieved have been expanded to include things like empowerment, participation, social mobility, and cultural identity and ecological objectives have shifted from resource management to ecosystem integrity and biodiversity (Munasinghe, 1993; Brown, 1998).

\subsection{Complexities of Sustainability}

Generally, ecosystem sustainability is to be achieved by pursuing the development of each of these narrower categories (socio-economic, political, and environmental) simultaneously (Haberl et al., 2004). This is because the ability of ecosystems to sustain productivity and biodiversity and thereby to sustain society with its demands for ecosystem services and resources is dependent on very complex interactions between the various species within the ecosystems, and between the ecosystems and the biological or human environment (Robért, 2000, Deal and Pallathucheril, 2009). Thus, it would be extremely foolish to ignore one category over the other as they all influence a land use project's sustainability in one way or the other. Hewitt and Hernandez-Jimenez (2010) argues that if progress is to be made in natural resource management that is genuinely sustainable at all levels, then these different categories of sustainability must be solved together, with each of the varying perspectives seen in their shared context. In favour of such arguments, social, environmental, and economic aspects are increasingly being integrated into forest management projects. However, the primary challenge facing such projects is how to build consensus among all stakeholders around the issues of sustainability. While sustainable development has been widely accepted as an international standard, for the local stakeholders in many African countries, it remains a concept that infringes on their rights. As explained by Reid and Schwab (2006) in many cases the concept is treated with suspicion in the context that projects are out to seek material or political benefit instead of advancing livelihood needs of local people. Thus, the ideological content of the sustainable development concept is either not well understood by the local people or poorly presented to them. This conflicting perception impedes effective implementation of sustainable projects. To reduce these misconceptions we need to improve our understanding of the livelihood and cultural dynamics of local communities.

\section{Research Methods}

\subsection{Afram Plains: Study Area Profile}

The study was conducted in the Sekyere East Afram Plain (SEAP) district (latitudes 0 and 


\section{Macrothink}

longitude $07^{\circ}$ ) in the Republic of Ghana. (Figure 1) The selected villages were located in the off-reserved forest. Forests in Ghana are divided into those in reserves and those outside reserves. In the off-reserves areas the traditional customary system of communal ownership is applicable. In these areas, the Chief (often referred to by his seat of office, the 'stool') is the custodian of the land on behalf of the community. Thus, land allocation rites for agricultural practices or other development are reserved for the chief. Falling within the transition zone between the northern Sudan savannah and the more Guinean savannah, the vegetation is dominated by a mosaic of forests and savannah vegetation (Codjoe and Owusu, 2011). Economic trees such as Antiaris africana, Afzelia africana, Celtis zenkeri, Africa mahogany, and Milicia excelsa are supported in these forests. Riverine forests occur along the rivers and streams and the larger stretches are cultivated by villagers who settle near them. The area is characterised by high temperatures with an annual rainfall in the district ranging between $1300 \mathrm{~mm}-1400 \mathrm{~mm}$. The soils are mostly poorly drained sandy loam (Appiah, 2013). The area has dual agricultural potential i.e. savannah and forest agriculture making these area of the country an important area for forestry and agricultural practices. Factors such as wildfires and illegal loggings have contributed to the almost total destruction of forests in these areas. Halting the trend of forest destruction in the area is a key goal of the government of Ghana.

The estimated current human population within the District (Sekyere Afram plains) is 23487 of which 12583 are males and 10904 are females. The annual percentage growth rate is 2.5 while the rate for the whole of Ghana is 1.9. Expected changes in population over the next 20 years are shown in Figure 2. The population density is 22.7 inhabitants per $\mathrm{km}^{2}$. As in other rural areas of Ghana the inhabitants are mostly farmers who are engaged in peasant farming.

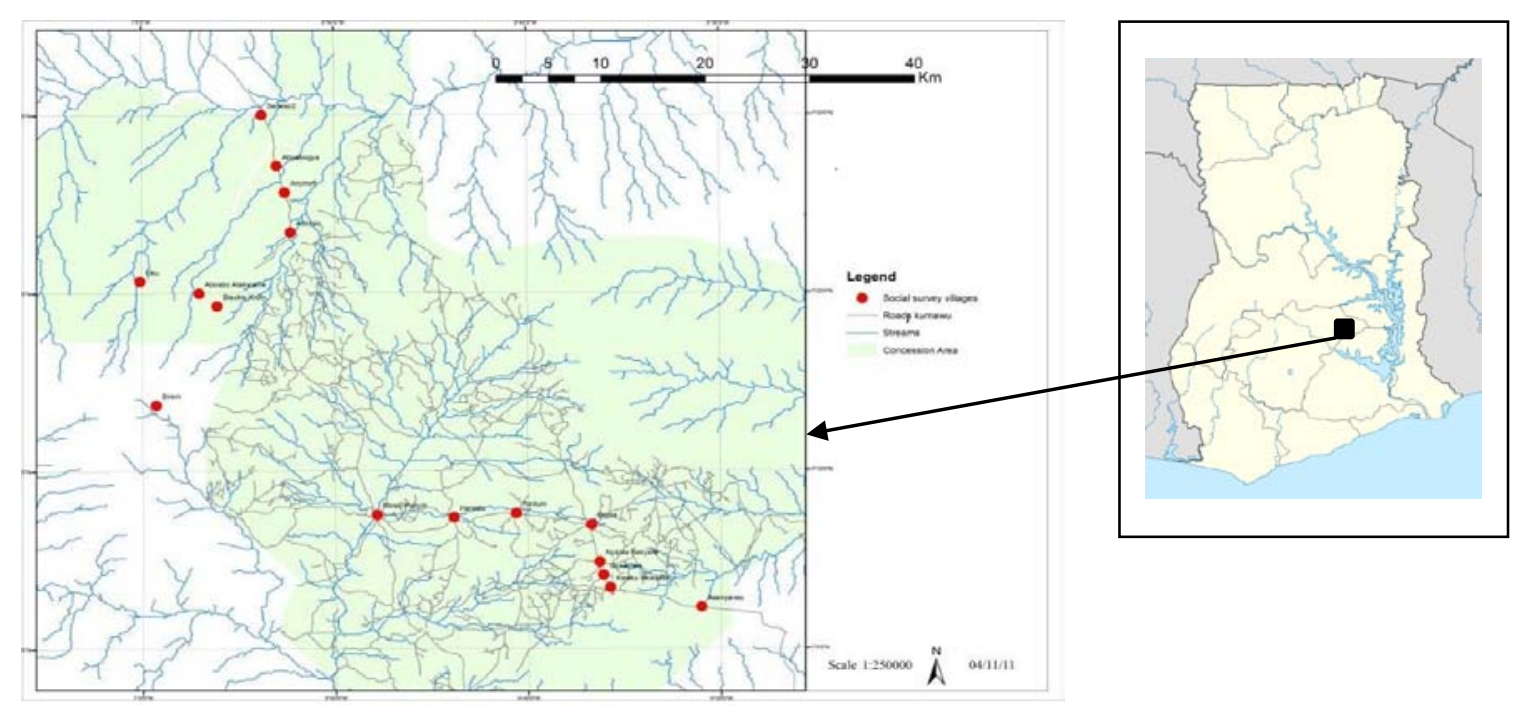

Figure 1. Map showing the location of the studied villages in Ghana 


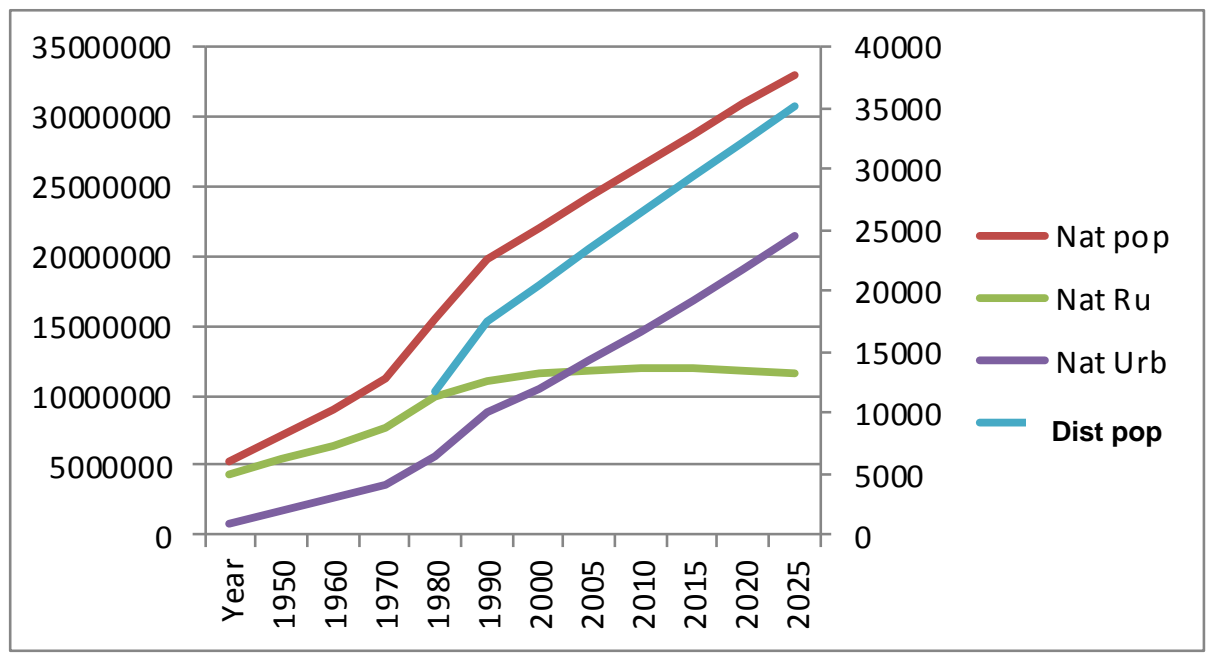

$($ Nat pop $=$ national population, $\mathrm{Nat} \mathrm{Ru}=$ national rural population, Nat Urb= national urban population, Dist pop = district population)

Figure 2. Projection of human population in the Sekyere East District compared to the national population.

\subsection{Data Gathering and Analysis}

The primary source of data was through field interviews of farming households. The interviews were performed with semi-structured questionnaire. All interviews were carried out face-to-face by some staff of the Forestry Research Institute of Ghana. In total, 600 households were sampled from 16 villages (Figure 1). The villages (number of samples in bracket) include Aboabo Atakwame (10), Aboabogya ( $\mathrm{N}=12)$, Adonso ( $\mathrm{N}=40)$, Anyinofi $(\mathrm{N}=60)$, Asanyanso $(\mathrm{N}=60)$, Birem $\mathrm{N}=20)$, Blackiekrom $(\mathrm{N}=10)$, Dome $(\mathrm{N}=80)$, Gyaaman $(\mathrm{N}=20)$, Hamidu $(\mathrm{N}=60)$, Kwaku Nkwanta $(\mathrm{N}=20)$, Mossi Panyin( $\mathrm{N}=60)$, Nyamebekyere $(\mathrm{N}=40)$, Oku( $\mathrm{N}=40)$, Seneso $2(\mathrm{~N}=48)$, Tuntum $(=20)$. Supplementary data were obtained through the review of existing research papers and reports (including district reports). Data collected centred on livelihood systems and farmers opinion on the agroecosystem status and the causes of deforestation in the area. SPSS (Statistical Package for the Social Sciences) was used for statistical analysis of data using descriptive (mean, standard deviations, frequencies, charts etc) statistics.

\section{Findings}

\subsection{Social Characteristics of Respondents}

Of all the household heads interviewed, $82 \%$ were males and $18 \%$ were females (Table 1 ). In terms of household age composition, majority (65\%) of the respondents were aged between 26-45 years, and 29\% above 45 years. The mean household size was 4 , estimated considering all members who reside in the households and included those who were temporally absent at the time of the survey. The household members are mostly young falling within the age range of $0-25$ years. Both the population distribution by age and house sizes of respondents reflects a typical pattern of population structures in rural Africa as a whole: high young population 
(71\%) under the age of 45 . The literacy rate among the respondents was low. Most of the respondents (92\%) were migrants or settler farmers and have moved in from different part of Ghana. Some have rented or leased land from the chief or from other migrant settlers. Only few $(8 \%)$ claimed to be native to the area (Table 1$)$. The human population in the survey villages ranged from 70 to 900 .

Table 1. Socio-economic characteristics of farmers

\begin{tabular}{|c|c|c|c|}
\hline Code & Socio-economic characteristics & Frequency(f) & Percentage (\%) \\
\hline \multirow[t]{3}{*}{1} & Gender (household head $(\mathrm{N}=600)$ ) & & \\
\hline & Male & 495 & 82 \\
\hline & Female & 105 & 18 \\
\hline \multirow[t]{3}{*}{2} & Gender (household members(N=2163)) & & \\
\hline & Male & 1168 & 54 \\
\hline & Female & 996 & 46 \\
\hline \multirow[t]{5}{*}{3} & Age group (years) of heads(N=600) & & \\
\hline & $0-25$ & 34 & 6 \\
\hline & 26-35 & 127 & 21 \\
\hline & $36-45$ & 264 & 44 \\
\hline & $>45$ & 175 & 29 \\
\hline \multirow[t]{5}{*}{4} & Household size (N=600) & & \\
\hline & $1-3$ & 174 & 29 \\
\hline & 4-6 & 328 & 55 \\
\hline & $7-9$ & 81 & 13 \\
\hline & $>10$ & 17 & 3 \\
\hline \multirow[t]{3}{*}{5} & Tenancy $(\mathrm{N}=600)$ & & \\
\hline & Indigenous & 48 & 8 \\
\hline & Migrants & 552 & 92 \\
\hline \multirow[t]{4}{*}{6} & Type of houses $(\mathrm{N}=600)$ & & \\
\hline & Mud & 577 & 96 \\
\hline & Concrete & 21 & 3.5 \\
\hline & Other & 2 & 0.3 \\
\hline
\end{tabular}

Household size $($ means $)=4.4(\mathrm{SE}=0.11$, lower bound $=4.2$, Upper bound $=4.7)$

\subsection{Livelihood Strategies}

\subsubsection{Occupation and Land Holdings}

The majority (76\%) of the people in the study area depend on farming (agriculture) as a source of livelihood. For $23 \%$, charcoal production is their main source of livelihood, whiles $1 \%$ were either teachers, traders or pensioners. The average land owned or leased per household is 9 acres (S.E $=0.92$, lower limit $=8$ and upper limit $=11)$ of which 6 acre $(\mathrm{S} . \mathrm{E}=$ 0.92 , lower limit $=6$ and upper limit $=7$ ) is under production (Figure 3). 


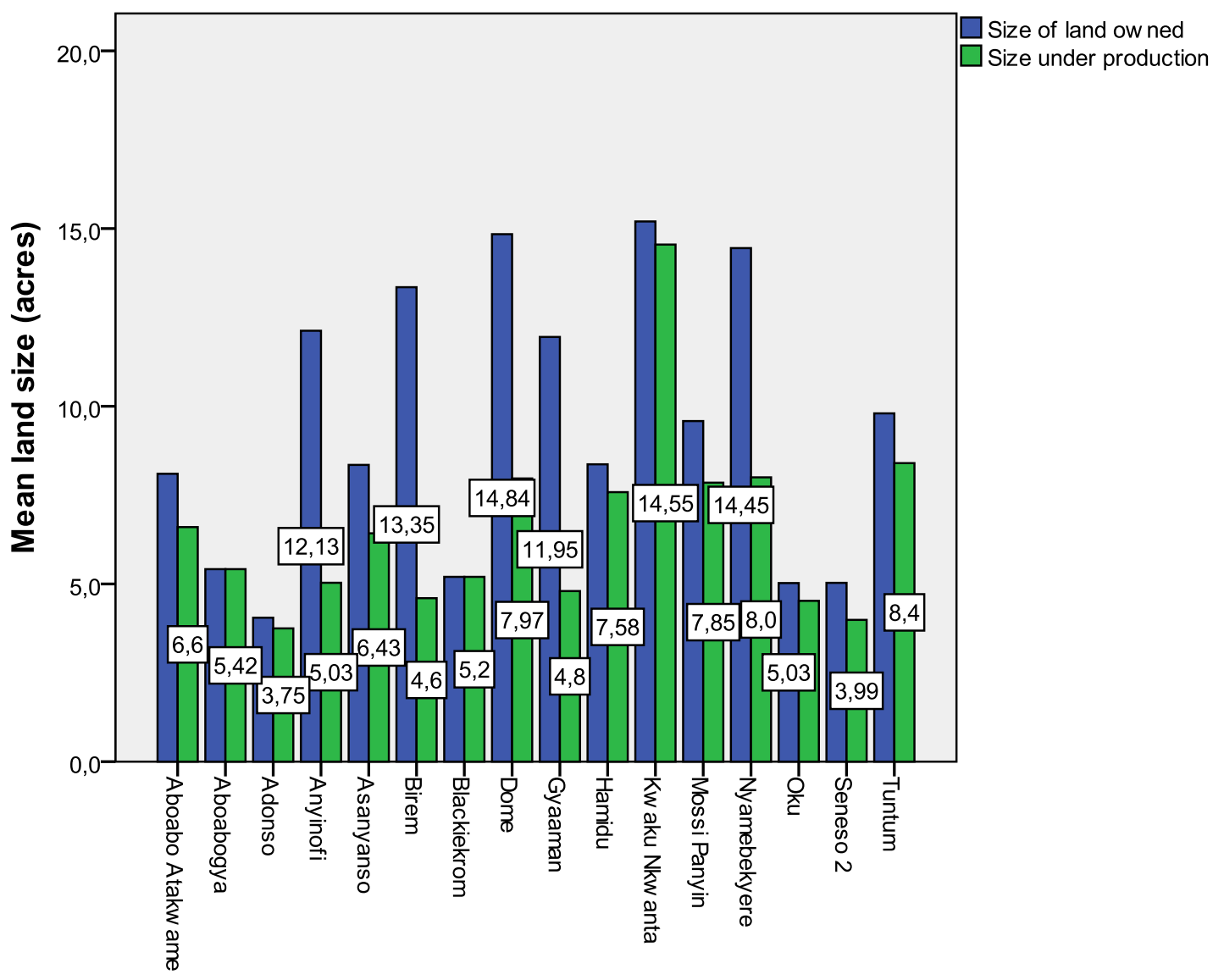

Settlement/village

Figure 3. Land holdings per households

(Note: acre is the unit of measurement commonly used by local people in Ghana)

\subsubsection{Production and Incomes}

Mixed farming and monocropping are the major farming systems of the respondent. The three major food crops that are grown either as monocrop or in mixed systems are maize, cassava, and yam. Other crops included in the mixed systems are pepper, garden egg, cocoyam, groundnuts, and beans. Rice is often grown as monocrop. In addition every household keeps some livestock including sheep, goats, and chicken. The respondents crop output is low. Based on their responses, about 0.6 tons of maize is produced per acre. Of which about half was consume per household and the rest sold. Table 3 show the household productivity and consumption level. The average annual income of respondents from farming was 452 euro for farmers while it was 324 euro for charcoal producers (Table 4). This income corresponds to a mean of $308(\mathrm{SD}=770) 50 \mathrm{~kg}$ bags of charcoal produced from an average of $30(\mathrm{SD}=56)$ trees $(10-20 \mathrm{~cm} \mathrm{dbh})$ at a price of $2 \mathrm{GHC}$. The results show that the majority of those who depend on charcoal production as livelihood source belong to the young age group of 20-35. Charcoal production is controlled by individuals or groups who have trading arrangements with agents or buyers from neighbouring towns and cities. 
Table 3. Household production units and productivity

\begin{tabular}{|l|c|c|c|}
\hline Units/quantity & \multicolumn{3}{|c|}{ Agricultural food crop } \\
\hline $\begin{array}{l}\text { Total land size under production } \\
\text { Mean acres(SD) }\end{array}$ & Maize & Cassava & Yam \\
\hline $\begin{array}{l}\text { Total quantity produced per year } \\
\text { Mean number of 50 kg bags of maize or } \\
\text { cassava/ tubers of yam (SD) }\end{array}$ & $12(18.1)$ & $3(16.6)$ & $1822(6314.6)$ \\
\hline $\begin{array}{l}\text { Total quantity consumed } \\
\text { Mean number of 50 kg bags of maize or } \\
\text { cassava/ tubers of yam (SD) }\end{array}$ & $1.6(3)$ & $0.8(6.5)$ & $313(369.1)$ \\
\hline
\end{tabular}

$S D=$ standard deviation in parenthesis.

This data should be taken with caution due the process of estimation that relied on recollection

Table 4. Household income levels

\begin{tabular}{|l|c|c|c|c|}
\hline Occupation & \multicolumn{3}{|c|}{ Statistical parameter } \\
\hline & \% respondents & $\begin{array}{c}\text { Mean income } \\
\text { (GHC) }\end{array}$ & $\begin{array}{c}\text { Mean income } \\
\text { (Euro) }\end{array}$ & Std. Error \\
\hline Charcoal & 138 & 615 & 324 & 62,4 \\
\hline Farming & 456 & 858 & 452 & 80,2 \\
\hline Trading & 4 & 49 & 26 & 10,3 \\
\hline Other sources (e.g., Gov service, carpentry) & 2 & 67 & 35 & 25,7 \\
\hline Total Average & 600 & 397.25 & 209.25 & \\
\hline
\end{tabular}

Rate $1 \mathrm{GHC}=1.9$ Euro

\subsubsection{Tree Species of Cultural Significance and Availability:}

In the studied villages, Kane is the most preferred species for charcoal production. The main species used for charcoal production and preferred alternative species are presented on Table 5.

Table 5. Tropical tree species that are important for charcoal production $(\mathrm{N}=600)$

\begin{tabular}{|l|l|l|l|l|}
\hline Tree species & Scientific name & Family & $\begin{array}{l}\text { Star } \\
\text { rating* }\end{array}$ & $\begin{array}{l}\text { Other } \\
\text { Socio-ecolo } \\
\text { gical value }\end{array}$ \\
\hline $\begin{array}{l}\text { Species used most } \\
\text { Kane }\end{array}$ & Anogeissus leiocarpus & Combretaceae & Green & 2 \\
Wagyedumpaboa & Berlinia spp & Leguminosae & Green & $2,3,9$ \\
Papadua, & Ficus sur & Moraceae & Green & $2,4,6,7$, \\
Potrodom, & Afzelia africana & Fabaceae & Red & $1,2,3,5,6,7$ \\
Sonkyi & Erythrophleum ivorense & Ceasalpinaceae & Pink & 2,3 \\
\hline Alternative species & Allanblackia parviflora & Guttiferae & Other & 3,4 \\
Dawadawa & Parkia biglobosa & Leguminosae-Mim & Other & $4,6,9$ \\
Kakapenpen & Rauvolfia vomitonia & Apocynaceae & other & $2,3,4$ \\
\hline
\end{tabular}




\begin{tabular}{|l|l|l|l|l|}
\hline Okanto & Zanthoxylem xanthoxlyoides & Rutaceae & Green & 2,7 \\
Krayie, & Pterocarpus erinaceus & Fabaceae & Other & $1,2,3,4$ \\
Mahogany & Khaya senegalensis & Ceasalpinaceae & Green & $1,2,3$ \\
Cassia, & Cassia siamea & Leguminosae-caes & Other & 6,9 \\
Odum, & Milicia excelsa & alpinioideae & Scarlet & $1,2,3,7$ \\
Senya & Danielia oliveri & Moraceae & Scarlet & $1,2,3$ \\
Neem & Azadirachta indica & Ceasalpinaceae & Other & 1,2 \\
Kranku (Shea butter) & Vitellaria paradoxa & Sapotaceae & Other & $2,4,8$ \\
\hline
\end{tabular}

Roofing (1), medicinal (2), timber (3), food (4), mortar making (5), protecting stream (6), sacred places (7), shea butter (8), soil improvement (9),. *This was developed by Hawthorne and Abu-Juam (1995) and used by the Forestry Commission of Ghana for similar site assessment and rating of species according to conservation needs. The species are assigned a star category based on its rarity in Ghana and internationally) (Green- No particular conservation required, Red= Common, but under pressure from exploitation. Need careful control, Pink = Common and moderately exploited as timber, Scarlet $=$ species are the most overly exploited $(>200 \%$ of AAC), Other $=$ unknown.

\subsubsection{Perception on Key Drivers of Biodiversity Loss}

When asked to give the single most important cause of biodiversity loss in the area, the respondents unanimously mentioned charcoal production activities. On the second most important cause, only few (15\%) suggested agriculture was a significant part of the problem of biodiversity loss while $75 \%$ suggested the annual bush fires resulting from hunting and escaped agricultural fires. Results also show that majority (73\%) of the respondents think that all timber trees including those for charcoal production will be exhausted in less than a year (Table 6). The same majority of respondents have the opinion that the ecosystem is severely degraded and that all the important species of cultural and economic values have been completely depleted or facing extinction.

Table 6. Opinion on the availability duration of important tropical tree species including charcoal species

\begin{tabular}{|l|c|c|}
\hline Years & Frequency of responses & \% responses \\
\hline 0 & 440 & 73 \\
\hline $1-3$ & 111 & 18.5 \\
\hline $4-6$ & 33 & 5.5 \\
\hline $7-9$ & 8 & 1.3 \\
\hline $10-13$ & 6 & 1 \\
\hline $15-20$ & 2 & 0.3 \\
\hline Total & 600 & 100 \\
\hline
\end{tabular}




\section{Discussion}

\subsection{Factor Driving Biodiversity Loss}

The majority of the stakeholders agree that there is forest habitat degradation that is leading to the loss of biodiversity including culturally and economically important timber tree species. The same view was shared by the Ministry of Environment and Science in the National Biodiversity Strategy for Ghana report (GoG, 2002; Appiah, 2013). In that report the forest zones including the dry semi-deciduous forest appear to have lost significant numbers of economic timber species. For instance, the populations of tree species such as Khaya anthotica, Milicia excelsa, Aningeria sp, Albizia ferruginea, Triplochiton scleroxylon, Entandrophragma angolense, Entandrophragma cylindricum, Entandrophragma utile, Guibourtia ehie, Pterygota macrocarpa normally present in the dry semi-deciduous forest zone, have reduced significantly and in some areas the species record only about a tree per hectare (Hawthorne and Abu-Juam, 1995; Appiah, 2013). The report even suggested that Talbotiella gentii, a tree species found only in Ghana and known to be located in the study zone (GoG, 2002) has been completely depleted from the study area. This species is rare internationally as well as being listed on the IUCN Red List as Critically Endangered (IUCN, 2010) and attention to its conservation has been raised (Boshier et al., 2011). So the observations of the local people are corroborated by other findings.

The respondents listed charcoal production, farming, and wildfires as the three main causes of biodiversity loss and environmental degradation. As suggested in this study, the leading cause is chopping of trees for charcoal production. With regard to agricultural activities, the local people have different views on the impact of their farming practices on biodiversity. Many people thought the nature of their agricultural practices had much less impact on biodiversity loss. This is in contrast to the findings in several areas in Ghana and other regions where shifting cultivation is known as one of the leading causes of environmental disturbances and biodiversity loss (Angelsen, 1995; Pearce, 1999; Richards, 2000; Geist and Lambin, 2002; IUCN, 2006; FRA, 2010). These revelations underscore the point that conditions prevailing in a region or a specific area must be well understood before initiating resource management projects if a more sustainable development process is to be facilitated.

While it is true that some of the respondents do undertake charcoal production activities which are detrimental to the environment and must be rectified, it was also argued that their behaviour was influenced by economic and subsistence needs. Subsistence activities have dominated deforestation causes in the tropics to date (FRA, 2010). In local people's endeavour to safeguard their livelihood in the short term, they further undermine the sustainability of the resources on which their future subsistence depends. However, the good news is that, as their responses suggest, the producers' activities are not conducted in an organised fashion with influential individuals or companies behind it. They are carried out by often very young people whose only concerned is with the short-term gains, and in their current condition have little or no real interest in long-term sustainable development. Thus, lack of economic opportunities is the principal factor driving their destructive activities that is causing the loss of biodiversity and degrading the environment in the area. That means under 
this ownership of responsibility, this serious problem can be addressed by introducing economic opportunities to the area, especially for the young people. This will not only improve livelihood, but could also help to reduce emission from deforestation and forest degradation. Deforestation and forest degradation are important contributors to climate change, constituting 20-25\% of global anthropogenic GHG emissions, and are the main source of emissions from many developing countries (Karousakis, 2006)

Education is a critical tool for achieving sustainability. Unfortunately, the majority of the people had no education or had just about primary education. Thus, the livelihood capabilities that include being able to find and make use of livelihood opportunities are limited for the people. Livelihood capabilities which also include gaining access to and using information, exercising foresight, experimenting and innovating, and exploiting new opportunities and resources (Chambers and Conway, 1992) are limited as well. Therefore, a program for building up required local people's capabilities or competencies is essential for ensuring sustainable forest and environmental resources management in the area.

The demographic trend show that the population is growing. Although the mean household size is lower than the regional (5.3) and national (5.1) averages, this demographic trend may escalate the demand for agricultural lands and as well accelerate charcoal burning activities with new entrants into the business. Unfortunately, there are no programmes or projects emphasizing rural youth development in the area. In Ghana, as in other African countries, there is an obvious lack of attention on the youth, especially rural youth, and their needs when it comes to the implementation of educational and development projects by both government institutions and the private sector. Attention to rural youth development must be priority in efforts to introduce sustainable resource management.

\subsection{Sustainable Management Action Areas}

Agriculture can and is expected to be economically viable for small-scale farmers. However, the average annual incomes from the respondents' production activities are very low. These income levels are consistent with values often recorded for rural farmers in Ghana engaged in small scale farming. The low agricultural outputs are in part due to smaller land holdings and poor management practices. The average land holding of respondents under cultivation was about 2 hectare. In relation to management practices, for instance, only about 0.2 tonnes of maize is produced per hectare. At the national level, the average yield of maize in tonnes per hectare is 1.5. The potential is estimated at 2.5 tonnes per hectare (at local practices). Similarly, the potential for cassava yield is 28 tonnes per hectare and 20 tonnes per hectare for yam. Low levels of production are a regional problem that is affecting food security in Africa (Sanchez et al. 2009; Sasson, 2012). This agricultural productivity situation in the studied area dictates the need for diversification and intensification of farming systems to successfully combine increased food security, cash generation and biodiversity conservation Sanchez et al., 2009; Sasson, 2012. Farm diversification will also lead to farmers needing even less land to sustain their household and as a result less shifting cultivation practices. In fact there is some evidence that increasing agricultural productivity by fostering more value-adding per worker, can help to reduce deforestation (Angelsen and Kaimowitz, 1999). 


\section{Ml Macrothink}

The study also reveals that some species are preferred over other and are extensively used for charcoal production due to their charcoal-yielding superior characteristics. Thus, there are many other species in the area that are limited in their use for charcoal resulting in only a few species being over exploited. Studies have generally shown that tree species with very frequent and diverse utility for the most part often end up being depleted (Fentahun and Hager, 2009). On the other hand, the overexploited species attest to the species value to local communities and if the communities are helped to plant these tree species, that can help improve local people livelihood as well as offer a better chance of conserving those species. There is no question that the local people recognise those species that have been lost or facing extinction from the agricultural landscapes. Their knowledge of the existing species and those that are extinct from agricultural landscape, in addition to the information gathered on local species preferences, should be able help make inputs in interventions that are aimed at enhancing diversity in the agro-ecosystems and serve as a baseline for monitoring impact of interventions (Kindt et al., 2006; Fentahun and Hager, 2009).

\section{Conclusion}

There may be many forces jeopardising farmers' forest resources in the study area but the leading cause has been cited as charcoal production. Charcoal burning was becoming increasingly a full time occupation for many young people as their families struggle with poor soil fertility and declining agricultural productivity. Though all farmers agreed that charcoal production is among the threats to biodiversity, they widely share the opinion that without any alternative economic activity abandoning charcoal production may not be an option for consideration to reduce biodiversity loss. According to a category of respondents, other livelihood strategies as farming, hunting, escaped agricultural fires have some impact on the loss of biodiversity as well and called for all these factors to be addressed collectively. Based on these finding, it is emphasized that significant financial and technological investment in agricultural diversification needs to be considered. This will significantly help forest dependent communities to diversify their economies and soften the impacts of farming on the biodiversity as well as reduce the charcoal production activities. It is further suggested that the successful rehabilitation or restoration of the agroecosystems would require an effective and efficient implementation of the educational programs considering the poor capabilities of local people currently. The potential of jointly advancing agroecosystem management and conservation of forest species with local participation can be realised if efforts are made to address cash income and energy needs of local people. Agroforestry systems including plantations development could be part of the solutions to achieving this goal (Fimbel and Fimbel, 1996; Garrity, 2004; Appiah, 2011).

\section{Acknowledgement}

Forestry Research Institute of Ghana staff (Francis, Emmanuel and Daniel) assisted with the data collection and they are greatly acknowledged. Thanks to Jessie, Grace and Dagmara Appiah for their cooperation during the field work. 


\section{References}

Angelsen, A., \& Kaimowitz, D. (1999). Rethinking the Causes of Deforestation: Lessons from Economic Models, World Bank Research Observer, 14(1), 73-98. http://dx.doi.org/10.1093/wbro/14.1.73

Angelsen, A. (1995). Shifting Cultivation and Deforestation“. A Study from Indonesia. World Development, 23(10), 1713-1729. http://dx.doi.org/10.1016/0305-750X(95)00070-S

Appiah, M. (2013). Tree population inventory, diversity and degradation analysis of a tropical dry deciduous forest in Afram Plains, Ghana. Forest Ecology and Management. (In press)

Appiah, M. (2011). Changes in species composition in a deciduous agroecosystem in Ghana following plantation establishment. Agrofor. Syst., 82, 57-74. http://dx.doi.org/10.1007/s10457-011-9459-3.

Appiah, M., Blay, D., Damnyag, L., Dwomoh, F., Pappinen, A., \& Luukkanen, O. (2009) Dependence on forest and tropical deforestation in Ghana. Environ Dev Sustain, 11(3), 471-487. http://dx.doi.org/10.1007/s10668-007-9125-0

Appiah, M., Damnyag, L., Blay, D., \& Pappinen, A. (2010). Forest and agroecosystem fire management in Ghana Mitigation and Adaptation of Strategies for Global Change, 15(6) 551-570. http://dx.doi.org/10.1007/s11027-010-9236-z

Appiah, M. (2001). Co-Partnership in Forest Management: The Gwira-Banso Joint Forest Management Project in Ghana. Environment, Development and Sustainability, 3(4), 343-360. http://dx.doi.org/10.1023/A:1020879510134

Bamfo, R. (2005). Forestry reforms, how far, which way? In: Opoku, K., Nketiah, K.S. and Arthur, E. 2005. Reconciling forest policy reform with forest legislation. Workshop proceedings 5. Tropenbos International, Wageningen, the Netherlands 2005.48pp.

Boshier, D., Dompreh, D., \& Swaine, M., (2011). Talbotiella gentii: genetic variation and conservation. A case study and teacher's notes. In: Forest Genetic Resources Training Guide. Edited by Boshier D, Bozzano M, Loo J, Rudebjer P. Biodiversity International, Rome, Italy.

Brundtland, G. (1987). Our Common Future: Towards Sustainable Development; the World Commission on Environment and Development, The United Nations: Geneva, Switzerland, 1987; Available online: http://www.un-documents.net/wced-ocf.htm (accessed on 20 March 2009).

Brown, P. G. (1998). Towards an Economics of Stewardship: the Case of Climate. Ecological Economics, 26,11-21. http://EconPapers.repec.org/RePEc:eee:ecolec:v:26:y:1998:i:1:p:11-21

Byron, N. (1997). International development in forestry and land management: the process and the players. Commonwealth Forestry Review, 76(1) 61-67.

Chambers, R., \& Conway, G. (1992) Sustainable Rural Livelihoods: Practical Concepts for the 21st Century. IDS Discussion Paper 296, Institute of Development Studies, Brighton, UK. 
Codjoe, S. N. A., \& Owusu, G. (2011). Climate change/variability and food systems: Evidence from the Afram Plaines, Ghana. Regional Environmental Change, 11(4), 753-765. http://dx.doi.org/10.1007/s10113-011-0211-3

Deal, B., \& Pallathucheril, V. (2009) Sustainability and Urban Dynamics: Assessing Future Impacts on Ecosystem Services. Sustainability, 1, 346-362. http://dx.doi.org/10.3390/su1030346

FAO. (2003). Sustainable forest management and the ecosystem approach: two concepts one goal. Wilkie M.L., Holmgren P. and Castaneda F., FAO Working Paper FM25, FAO Rome.

FAO/ITTO/INAB. (2003). International Conference on the Contribution of Criteria and Indicators for Sustainable Forest Management: The Way Forward. Final Report, Volume 1. Rome.

Fentahun, M., \& Hager, H. (2009). Integration of indigenous wild woody perennial edible fruit bearing species in the agricultural landscapes of Amhara region, Ethiopia. Agroforestry Systems, 78(1), 79-95. http://dx.doi.org/10.1007/s10457-009-9239-5

Miller, R. (1997). Urban Forestry: Planning and Managing Urban Green spaces. Upper Saddle River, New Jersey: Prentice Hall. 502p.

Fimbel, R. A., \& Fimbel, C. C. (1996). The role of exotic conifer plantations in rehabilitating degraded tropical forest lands: a case study from the Kibale Forests in Uganda. For. Ecol Manage, 81, 215-226. http://dx.doi.org/10.1016/0378-1127(95)03637-7

FRA. (2010). Global forest resources assessment 2010, (FRA2010/077). FAO, Italy Rome.

Garrity, D. P. (2004) Agroforestry and the achievement of the millennium development goals. Agrofor. Syst., 61, 5-17. http://dx.doi.org/10.1023/B:AGFO.0000028986.37502.7c

Geist, H. J., \& Lambin, E. F. (2002). Proximate causes and underlying driving forces of tropical deforestation. Bioscience, $143-150$. http://dx.doi.org/10.1641/0006-3568(2002)052[0143:PCAUDF]2.0.CO;2

Geist, H. J., \& Lambin, E. F. (2001). What drives tropical deforestation? A meta-analysis of proximate and underlying causes of deforestation based on subnational case study evidence. (LUCC Report Series; 4, LUCC website: http://www.geo.ucl.ac.be/LUCC, retrieved 3.1.2013)

GoG. (2002). National biodiversity strategy for Ghana. Ministry of Environment and Science. Ghana. 53p.

Grainger, A. (1993). Controlling tropical deforestation. Earthscan: London.

Hawthorne, W. D. (1989). The flora and vegetation of Ghana's forests. In: Ghana forest inventory proceedings (pp. 8-13). Overseas Development Agency/Ghana Forestry Department, Accra.

Hawthorne, W. D. (1994). Fire damage and forest regeneration in Ghana. Forestry inventory 
and management project of the Ghana Forestry Department. ODA Forestry Series No. 4 Natural Resource Institute, Chatam Maritime, Kent, UK, pp 1-18.

Hawthorne, W.D., \& Abu-Juam, M. (1995). Forest Protection in Ghana (with particular reference to vegetation and plant species): IUCN, Gland, Switzerland and Cambridge, U.K.

Haberl, H., Wackernagel, M., \& Wrbka, T. (2004). Land use and sustainability indicators: An introduction. Land Use Policy 2004, 21, 193-198. http://dx.doi.org/10.1016/j.landusepol.2003.10.004

Hewitt R., \& Hernandez-Jimenez, V. (2010). Devolved Regions, Fragmented Landscapes: The Struggle for Sustainability in Madrid. Sustainability 2010, 2, 1252-1281. http://dx.doi.org/10.3390/su2051252.

IUCN. (2010). IUCN Red List (September, 2010), http://www.iucnredlist.org.

IUCN. (2006). Forest landscape restoration to meet Ghana's deforestation Challenges, IUCN (http://www.IUCN.org/en/news/archive/2006/newfebruary06.htm)

Karousakis, K. (2006). Initial review of policies and incentives to reduce GHG emissions from deforestation. Organisation for Economic Co-operation and Development. International energy agency, www.oecd.org/env/cc/aixg

Kindt, R., Van Damme, P., Simons A., J. (2006). Tree diversity in western Kenya: using profiles to characterise richness and evenness. Biodiversity Conservation, 15, 1253-1270. http://dx.doi.org/10.1007/978-1-4020-5208-8_11

Munasinghe, M. (1993). Environmental Economics and Sustainable Development, World Bank, Wash. DC, USA.

Ostrom, E. (2007). A diagnostic approach for going beyond panaceas", Proc. Natl. Acad. Sci., Published online before print September 19, 2007, http://dx.doi.org/10.1073/pnas.0702288104

Palanivel, T. (1999). Towards sustainable development: An overview of concepts, indicators and framework. UNU/IAS Working paper No 86.

Pearce, D., Putz, F., \& Vanclay, J. (1999). A Sustainable Forest Future? Report prepared for the UK DFID/NRA.

Repetto, R. (1988). The forest for trees? Government policies and the misuse of forest resources. World Resources Institute. Washington DC. 105 p.

Margaret Reid, M., \& Schwab, W. (2006). Barriers to Sustainable Development: Jordan's Sustainable Tourism Strategy. Journal of Asian and African Studies 2006 41: 439. http://dx.doi.org/10.1177/0021909606067408

Richards, M. (2000). Can Sustainable Topical Forestry be Made Profitable? The Potential and Limitations of Innovative Incentive Mechanisms. World Development, 28(6), 1001-1016.

Robért, K. H. (2000). Tools and concepts for sustainable development, how do they relate to 
a general framework for sustainable development, and to each other? Journal of Cleaner Production, 8 (2000) 243-254. http://dx.doi.org/10.1016/S0959-6526(00)00011-1,

Sanchez, P., Denning, G., \& Nziguheba, G. (2009). The African green revolution moves forward. Food Secur. 2009, 1, 37-44. http://hdl.handle.net/10.1007/s12571-009-0011-5

Sasson, A. (2012). Food security for Africa: An urgent global challenge. Agr. Food Secur. 2012, 1, 1-16. http://dx.doi.org/10.1186/2048-7010-1-2

Tallis, H., Kareiva, P., Marvier, M. \& Chang, A. (2008). An ecosystem services framework to support both practical conservation and economic development, PNAS, Proceedings of the National Academy of Sciences, 105 (28), 9457-9464

Wagner, R. M., Cobbinah, J.R., \& Bosu, P. P. (2008). Forest Entomology in West Tropical Africa: Forest Insects of Ghana, Springer, P. O. Box 17, 3300 Dordrecht, The Netherlands, ISBN 978-1-4020-6506-4, 29p.

Wagner, M. R., \& Cobbinah, J.R. (1993). Deforestation and sustainability in Ghana: the role of tropical forests. Ghana Journal of Forestry, 91, 36-39.

World Commission on Environment and Development. (1992). Our Common Future, Chapter 2: Towards Sustainable Development. UN document, http://www.un-documents.net/ocf-02.htm, retrieved 13.1.2013.

\section{Copyright Disclaimer}

Copyright reserved by the author(s).

This article is an open-access article distributed under the terms and conditions of the Creative Commons Attribution license (http://creativecommons.org/licenses/by/3.0/). 